\title{
Marifete Erme Yöntemi Olarak Sohbet: Sülemî’nin Edebü mücâleseti'l-meşâyih ve hıfzi hurumâtihim Risâlesinin Tercüme ve Değerlendirilmesi
}

\author{
Soner Eraslan \\ Arş. Gör., İnönü Üniversitesi, İlahiyat Fakültesi, Tasavvuf Ana Bilim Dalı \\ Malatya/Türkiye \\ soner.eraslan@inonu.edu.tr \\ http://orcid.org/0000-0002-4293-9265
}

\section{Giriş}

Ebû Abdurrahman es-Sülemî (ö. 412/1021), dedesi Ebû Amr İsmail b. Nüceyd esSülemî’nin (ö. 366-376/981-991) yönlendirmesi ile tasavvuf yolunu seçmiş, ilk olarak Ebû Sehl es-Sülûkîye (ö. 369/980) intisâb etmiş ve Ebü'l-Kāsım en-Nasrâbâdî (ö. 367/977) eliyle de şeyhlik hırkasını giymiştir. Sülemî, gençlik yıllarının başında hadis tahsili için Nişabur'dan yola çıkmış, Horasan bölgesinin çeşitli beldelerini gezdikten sonra Irak ve Hicâz'a yönelerek dönemin birçok âliminden ders almıştır. Nişabur'a tekrar döndüğünde dedesinin vefat ettiğini öğrenmiş ve ondan kalan evi tekkeye çevirerek ömrünün geri kalanında -yaklaşık kırk yıl- burada telif ve tedris ile iştigal etmiştir. ${ }^{1}$

Şüphesiz Sülemî’nin tasavvuf ilmine en büyük katkısı, dağınık halde bulunan sûfî öğreti, yaşayış ve hal tercümelerini tedvin ederek bunları çeşitli başlıklar altında tasnif etmesidir. Onun külliyatına bakıldığında -hadisçi yönünün de etkisiyle olsa gerek- sûfîler hakkında neredeyse verdiği tüm bilgilerin, rivayet zinciri ile aktarıldığı görülmektedir. Bu durum Sülemînin ve eserlerinin en güvenilir kaynaklar arasında sayılmasına vesile olmaktadır. Öte yandan Ebû Nasr es-Serrâc ${ }^{2}$ (ö.

1 Alexander Knysh, Tasavvuf Tarihi, çev. İhsan Durdu (ìstanbul: Ufuk Yayınları, 2011), 124.

2 Sözgelimi Sülemînnin şatahât hakkında kaleme aldığı ilgili eser, Serrâc'ın el-Lüma'ından iktibas edilmiştir. bk. Ebû Nasr Abdullah b. Ali et-Tûsî es-Serrâc, el-Lümac, thk. Abdülkerim Mahmud - Taha Abdülbâkī Surûr (Bağdad: Mektebetü'l-Müsennâ, 1970), 453; Ebû Abdurrahman Muhammed b. Hüseyin es-Sülemî, "Risâle fi galațâti's-sûfiyye", thk. Gerhard Böwerıng, Mecmû'a-i Âsâr-ı Ebû 'Abdirrahmân esSülemî,3/469-470.

Geliş Tarihi/Received Date: 15.10 .2020

Kabul Tarihi/Accepted Date: 09.11.2021

\section{Araştırma Notu / Research Note}

Atıf/Citation: Eraslan, Soner. "Marifete Erme Yöntemi Olarak Sohbet: Sülemînnin Edebü mücâleseti'lmeşâyih ve hıfzị hurumâtihim Risâlesinin Tercüme ve Değerlendirilmesi”. Uludağ Üniversitesi İlahiyat Fakültesi Dergisi 30/2 (Aralık 2021), 633-652. https://doi.org/10.51447/uluifd.811028 
378/988), Muhammed b. İbrahim el-Kelâbâzî (ö. 380/990) gibi isimlerden etkilendiği görülen Sülemî; Ebû Nuaym el-İsfahânî (ö. 430/1038), Abdülkerim el-Kuşeyrî (ö. 465/1072), Ebû Osman el-Hücvîrî (ö. 465/1072) gibi isimleri tesiri altına alarak tasavvuf alanında iki nesli birbirine bağlayan bir köprü görevi üstlenmiştir. ${ }^{3}$

Sülemî, başta günümüze tam olarak ulaşan ilk sûfî tabakâtı Ṭabakātü’ș-șûfiyye ve tüm sûreleri kapsayan ilk işârî tefsir olma özelliğine sahip Hakāàiku't-tefsîr olmak üzere birçoğu risâle hacminde olan yüzü aşkın esere imza atmıştır. Bu eserlerin büyük bir kısmı sûfîlerin rivayetlerinden müteşekkil olup geri kalanı Sülemînnin tasavvuf anlayışını yansıtmaktadır. Fakat buna rağmen gerek görüşlerini zikrettiği sûfîlerden, gerekse yer yer farklı görüşler arasındaki tercihlerinden Sülemî̀nin hangi ekolü benimsediği anlaşılmaktadır.

Çalışmamızın Sülemî'nin sohbet ve sohbetin âdâbı üzerine kaleme aldığg Edebü mücâleseti'l-meşâyih ve ḥfẓi ḥurumâtihim risâlesi üzerine yoğunlaşması hasebiyle öncelikle yazarın çeşitli eserlerinde edindiğimiz sohbet kavramına dair yapmış olduğu tanım aralığını tespit etmeye çalışacağız. Akabinde risâle ve tahkiki hakkında bilgi verip adı geçen risâlenin tercüme ve değerlendirmesini sunacağız.

\section{Marifete Erme Yöntemi Olarak Sohbet}

Șahibe (صحب) kelime kökünden türeyen sohbet ve sâhib/ashâb kelimeleri "arkadaş, refîk, dost, yâren, eş" gibi anlamlara gelmekle birlikte, önde gelen birinin çevresinde toplanarak o kişinin düşünce, ve uygulamalarını benimseyip hayata geçirmek yahut mezhep, fırka veya bir akıma bağlanmak manalarını da içermektedir. ${ }^{4}$ Sülemî'nin benimsediği sohbet tanımı ise Âdâbü'ș-șohbe ve hünsü'l-'uşre'de belirttiği üzere şeyh, mürîd ve ihvân merkezli olup bu üç zümrenin birbiri ile olan ilişkileri üzerine kuruludur. Sözü geçen tanım şöyledir: "Sohbet, şeyhe ve büyüklere karşı hürmet ve hizmet; akrana karşı nasihat ve cömertlik iken küçüklere ve mürîdlere karşı ise irşâd, tedib ve hüsn-i edeb ile onlara sünneti ve ilmi öğretmektir." ${ }^{5}$ Öte yandan Allah ile kullar arasındaki sohbete de "istișhâb/(ستصحاب)" kavramı ile işaret eden Sülemî, Allah'ın sevdiği bazı kullarını dost edindiğini Ebû Abdullah b. elCellâ'nın (ö. 306/918) dilinden aktarmaktadır. ${ }^{6}$ Fakat Țabakătü'ṣ-sûfiyye'ye bakıldığında Sülemî̀nin şeyh ve mürîd özelinde gerçekleşen sohbet kavramını, aralarında birtakım nüanslar olmakla birlikte tanım aralığını genişlettiği görülmektedir. Sözgelimi sohbet kavramının iç içe geçmiş katmanlar olduğuna delâlet eden iltikâ, in-

3 Soner Eraslan, Tabakât Literatürünün Ortaya Çıkışı: Sülemînin Tabakâtu’s-Sûfiyye’si (İstanbul: İstanbul Üniversitesi, Sosyal Bilimler Enstitüsü, Yüksek Lisans Tezi, 2020), 31.

4 Luvis b Nikola el-Ma'lûf el-Yesûî Maclûf, el-Müncid fíl-luġa ve'l-ạlâm (Beyrut: Dârü'l-Meşrik, 2003), 507; Yusuf Hattâr Muhammed, el-Mevsû'atü'l-Yûsufiyye bi beyâni edilleti'ṣ-șâfiyye (Dimaşk: Dârü’tTakvâ, 2003), 393.

5 Ebû Abdurrahman es-Sülemî, “Âdâbü'ṣ-șuhbe ve hüsnü'l-'uşre”, Mecmû' $a$-i Âsâr-ı Ebû ‘Abdirrahmân es-Sülemî, thk. Meir J. Kister (Tahran: Merkez-i Neşr-i Danişgahi, 1369 hş), 3/69.

6 Sülemî, Țabakātü’ș-șufiyye, 177. 
tisâb, tevellü, ru'yet, mücâlese, refâkat gibi kelimelerin tümü sohbete işaret eden bu minvaldeki lafızlardır. ${ }^{7}$ Böylece Sülemî, zikrettiği kavramlarla şeyh-mürîd ilişkisinin sanıldığından daha girift ve derinlikli olduğunu Țabakāt'ın satır aralarında beyan etmektedir.

Şeyh ve müridin buluşması (iltikâa'/التقاء) ile başlayan sohbet, görmek (ru’yet/رؤية) ve aynı mecliste bulunma (mücâlese/بالساء) ile devam etmektedir. Sohbette bulunmak, bazı zamanlarda şeyh ve mürîdlerin birlikte yola çıkmaları (mürâfaka/مرافقa) şeklinde dile getirilmektedir. Ebû Osman Saîd b. İsmail el-Hîrî'nin (ö. 298/910), Şah İbn Şucâ el-Kirmânî̀ye (ö. 300/912) Ebû Hafs el-Haddâd'ı (ö. 303/915) ziyarete giden Kirmânîye refakati buna örnektir. ${ }^{8}$ Bu refâkatin ardından her iki sûfînin de Ebû Hafs'a bağlandığını (intimâ'/انتماء) görüyoruz. ${ }^{9}$ Sülemî, Ebû Osman el-Hîrî’nin Ebû Hafs'ın sohbetinde bulunmasını bir de şöyle ifade etmektedir: “'أخذ عنه طريقته yöntemini benimsedi." ${ }^{10}$ Sülemî’nin sohbete katılmayı ifade etmek için kullandığ1 bir başka kelimenin de intisâb (intisâb/نتساب) olduğu görülmektedir. Amr b. Osman el-Mekkî’nin (ö. 297/910) Cüneyd-i Bağdâdî’nin (ö. 298/909) sohbetine katıldı̆̆ını belirten Sülemî, bu durumu "كان يتسب إلى الجنيد في الصحبة/Cüneyd'in sohbetine intisâb ederdi." şeklinde açıklamaktadır. ${ }^{11}$

Sülemî, Țabakāâ'ında sûfîler hakkında bilgi verirken neredeyse hepsinin hangi şeyhin sohbetinde bulunduklarını belirtmektedir. Peki, sohbetin mahiyeti ve ehemmiyetinin ne olduğu, sohbet esnasında nasıl bir âdâb benimsenmesi gerektiği hususunda ne söylemektedir? Bu noktada Sülemî; Menâhicü'l-'ârifîn ${ }^{12}$, Beyânu ahvâli'ṣ-șâfiyye ${ }^{13}$, Risâletü ravzati'l-mürîdîn ${ }^{14}$ gibi birçok risâlesinde sâliklere tasavvuf

7 Ebû Abdurrahman Muhammed b Hüseyin Sülemî, Țabakātü'ș-șûfiyye, thk. Nureddin eş-Şerîbe (Kahire: Mektebetü'l-Hancî, 1969), ss. 48, 98, 103, 170, 200, 217, 228, 234, 273, 288, 307, 319, 326, 332, 373 , $378,434$.

$8 \quad$ Kuşeyrî er-Risâle' de Sülemî ile benzer nitelikteki şu rivayeti nakletmektedir: "(Ebû Osman Saîd b. İsmail el-Hirî), önce Şah Kirmânî daha sonra Yahya er-Râzî̀nin sohbetinde (صحب) bulundu. Ardından Şah Kirmânî ile birlikte Nişabur'a, Ebû Hafs el-Haddâd'ın yanına gitti. Ebû Hafs'ın yanında kalıp ondan icazet aldı. Ebû Hafs onu kızı ile evlendirdi." Abdülkerim el-Kuşeyrî, er-Risaletü'l-Kuşeyriyye, thk. Abdulhalim Mahmud - Mahmud b. Şerif (Kahire: Daru'ş-Şa‘b, 1989), 81; Benzer bir ifade Hücvirî’nin Keşfu'l-mahcûb'unda da zikredilmektedir: “Bidayette Yahya b. Muaz er-Râzînnin, bir müddet sonra Şah b. Şucâ el-Kirmanî̀nin sohbetinde (صحب) bulunmuştur. Ardından onunla birlikte Ebû Hafs elHaddâd'ın ziyaretinde bulunmak için Nişabur'a gitmiştir. Ebû Hafs'ın yanında kalmış ve ömrünü onun sohbetinde geçirmiştir." Ali b. Osman el-Hücviri, Keşfü'l-mahcûb, çev. İsmail Abdulhâdî Kandîl (Kahire: Şuunü'l-İslâmiyye, 1975), 345.

9 Sülemî, Țabakātü'ṣ-șufiyye, 115.

10 Sülemî, Țabakātü'ș-șuffiyye, 170.

11 Sülemî, Ṭabaḳātü'ṣ-șûfiyye, 200.

12 Ebû Abdurrahman Muhammed b Hüseyin es-Sülemî, "Menâhicü'l-‘ârifîn”, Mecmû‘ a-i Âsâr-ı Ebûu 'Abdirrahmân es-Sülemî, thk. Etan Kıster (Tahran: Merkez-i Neşr-i Danişgahi, 1369 hş).

13 Ebû Abdurrahman Muhammed b. Hüseyin es-Sülemî, "Beyânu ahvâli's-sûfiyye", Tasavvufun Ana İlkeleri Sülemi’nin Risaleleri, çev. Süleyman Ateş (Ankara: Ankara Üniversitesi, 1981). 
yol ve âdabını öğretilirken Âdâbü'ș-șohbe ve hünsü'l-'uşre $e^{15}$, Cevâmi'u âdâbi'ṣ-șuhbe $e^{16}$ gibi eserlerini doğrudan sohbetin âdâbı üzerine kaleme almıştır. Sohbet üzerine müstakil olarak yazdığı eserlerinden biri de Edebü mücâleseti'l-meşâyih ve hıfzi hurumâtihim'dir. ${ }^{17}$ Sülemî, âdeti olduğu üzere adı geçen risâlede ayet, hadis ve önde gelen bazı sûfîlerin sohbetle ilgili söylemlerini aktarıp yer yer bunları yorumlamaktadır. Böylece tasavvuf ilmi açısından son derece ehemmiyetli olan sohbet kavramını, dinî ve tasavvufî otorite ile meşru bir zeminde değerlendirmektedir. Bunun yanında şeyhlerin sohbetinde bulunmanın önemi, şeyhlere saygı duymanın gerekliliği, ihvân ile olan münasebetler, şeyhin mürîdlerine karşı vazifeleri, sûfîlerin sohbetin âdâbını terk etmeleriyle içine düşecekleri kötü durumlar gibi sohbetle ilintili birçok konuya temas edilmektedir. Risâle, hacminin küçüklüğüne mukabil sohbetin âdâbı hakkında geniş bir muhtevaya sahip olmasıyla dikkatleri celp etmektedir. Birçok eseri çeşitli vesilelerle Türkçe'ye kazandırılan Sülemî'nin Edebü mücâleseti'lmeşâyih ve ḥfẓi hurumâtihim risâlesini bu sebeple tercüme ederek tasavvuf araştırmalarına küçük bir katkıda bulunmak istedik. Böylece tasavvufun erken dönemindeki sohbet kavramı hakkındaki Türkçe literatürün bir nebze de olsa genişleyeceğini ümit etmekteyiz.

\section{Risâle Hakkında Bilgi}

Sülemî’nin Edebü mücâleseti'l-meşâyih ve ḥ̂f̣i hurumâtihim risâlesi, Kennedy Lee Honerkamp tarafından üç nüshanın mukayesesiyle tahkik edilmiştir. Risâlenin ilk ve tahkikin temelini oluşturan nüshası, Riyâd'da bulunan 2118 numaralı esSülemiyyât isimli mecmuada Zimmü tekebbüri'l-'ulemâ ile Zikru miheni'l-meşâyihi'șșûfiyye risâleleri arasında yer almaktadır. Riyâd'daki bu nüsha, Abdülhalîm elÜsrûşenî tarafindan hicrî 474 yılında istinsah edilip en eski nüsha olma özelliğini taşımaktadır. ${ }^{18}$ Tahran'da bulunan ikinci nüsha, 3989 numaralı mecmûada yer almaktayken ${ }^{19}$ Marakeş'teki üçüncü nüsha ise 1206 numaralı mecmûada bulunmaktadir. $^{20}$

14 Ebû Abdurrahman Muhammed b. Hüseyin es-Sülemî, "Risâletü ravẓati'l-mürîdîn”, Mecmû‘ a-i Âsâr-l Ebû 'Abdirrahmân es-Sülemî, thk. Muhammed Sûrî (Tahran: Merkez-i Neşr-i Danişgahi, 1369 hş).

15 Ebû Abdurrahman Muhammed b. Hüseyin es-Sülemî, Âdâbu'ṣ-șuhbe (Tanta: Dârü's-Sahâbe li't-Türâs, 1990).

16 Ebû Abdurrahman Muhammed b. Hüseyin es-Sülemî, "Cevâmicu âdâbi'ș-ș̂fiyye", Mecmûca-i Âsâr-l Ebû 'Abdirrahmmân es-Sülemî, thk. Etan Kohlberg (Tahran: Merkez-i Neşr-i Danişgahi, 1369 hş).

17 Ebû Abdurrahman Muhammed b Hüseyin es-Sülemî, "Edebü mücâleseti'l-meşâyih ve ḥıf̣̣i hurumâtihim", Mecmû'a-i Âsâr-ı Ebû 'Abdirrahmân es-Sülemî, thk. Kennedy Lee Honerkamp (Tahran: Merkez-i Neşr-i Danişgahi, 1369 hş), ss. 89-120.

18 el-İmam Muhammed b. Suûd el-İslâmiyye Üniversitesi'ndeki yazma eserler arasında bulunan birinci nüsha, 73-76 arasındaki varaklara tekabül edip 12 sayfadan müteşekkildir. Sülemî, "Edebü mücâleseti'l-meşâyih ve hııł̣i ḥurumâtihim", muhakkikin mukaddimesi, 91.

19 Meliku'l-Vataniyye Kütüphanesinde yer alan ikinci nüsha, 40-45 arasındaki varaklara tekabül edip 11 sayfadan müteşekkildir. Sülemî, “Edebü mücâleseti'l-meşâyih ve hı̣fẓi hurumâtihim”, muhakkikin 
Honerkamp, adı geçen risâlenin ne Keşfü'z-zünûn'da, ne Nureddin Şerîbe'nin Tabakātü'ṣ-șâfiyye'ye yazdığı mukaddimede, ne Fuat Sezgin'in Târîhu't-türâsi'l'Arabiyye'sinde ne de Süleyman Ateş'in Tis'atü kütüb fî Ușuli't-tașavvufi ve'z-zühd'ünde yer aldığını ifade etmektedir. Bu yönüyle risâle, son derece nadir bir eser olarak karşımıza çıkmaktadır. ${ }^{21}$

Risâle, Nasrullah Pürcevâdî editörlüğünde üç ciltten müteşekkil olarak yayına hazırlanan Mecmû́a-i Âsâr-i Ebû Abdirrahmān es-Sülemî kitabının üçüncü cildi içerisinde yer almakta olup 16 sayfadan oluşmaktadır. "Besmele", risâlenin başlığı ve

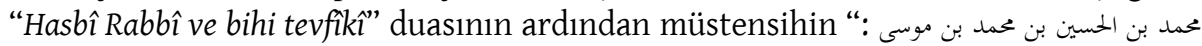
"sözleri ile risâlenin metnine geçilmektedir.

\section{Edebü mücâleseti'l-meşâyih ve hıfẓi hurumâtihim ${ }^{22}$ Risâlesinin Tercümesi}

$$
\text { بسم الله الرحمن الرحيم }
$$

(Rahman ve Rahîm olan Allah'ın adıyla)

$$
\text { أدب مجالسة المشايخ و حفظ حرماقم }
$$

(Şeyhlerle Bulunma ve Onlara Hürmet Etme Âdâbı)

$$
\text { حسبي ربي و به توفيقي }
$$

(Rabbim bana yeter ve muvaffakiyetim O'ndandır.)

1. Şeyh, İmam ve fâzıl Ebû Abdurrahmân es-Sülemî, şeyhlerin sohbetinde bulunma edebi hakkında şöyle söylemektedir: Hamd önsüz-sonsuz olarak âlemlerin Rabbi olan Allah'adır. Allah, Efendimiz Hz. Muhammed Mustafa'ya ve âline çokça salat ve selam eylesin. Şunu bilmelisin ki -Allah seni hakka tabi olmak hususunda muvaffak kılsın- zikri yüce olan Allah, küçüklere büyüklerine tabi olmayı ve onların âdâbı ile edeplenmeyi emrederek şöyle buyurmuştur: “...yüzünü ve özünü Bana çevirenlerin yolunu izle..." (Lokman/15). Yani “Tüm isteklerinde bana dönüp "Tüm isteklerinde Bana dönüp onlardan bürünmelerini istediğim âdâbla edeplenen kimselerin (yolunu izle)." Hz. Peygamber de şöyle buyurmuştur: "Küçük-

mukaddimesi, 92.

20 Hazâne İbn Yusuf yazmaları arasında yer alan üçüncü nüsha ise 187 ile 195 varakları arasında yer alıp 9 sayfadan müteşekkildir. Sülemî, "Edebü mücâleseti'l-meşâyih ve ḥ̂f̣i hurumâtihim”, muhakkikin mukaddimesi, 92.

21 Sülemî, "Edebü mücâleseti'l-meşâyih ve ḥıf̣i ḥurumâtihim”, muhakkikin mukaddimesi, 92.

22 Muhakkik, metinde geçen hadislerin tahricinin yanında adı geçen sûfîlerin hayatları hakkında da kısaca bilgi vermektedir. Buna ilave olarak söz konusu risâledeki ifadeler şayet Sülemî’nin diğer eserlerinde de zikredilmişse onlara işaret ederek ilgili bölüme atıfta bulunmuştur. 
lerimize merhamet, büyüklerimize saygı göstermeyen bizden değildir." ${ }^{23}$ Küçüklere duyulan merhamet onları tedip etmek, büyüklere gösterilen hürmet ve saygı ise onlara karşı âdâb-1 muaşerete uygun davranmak ve güzel bir edeple hizmetlerinde bulunmakla gerçekleşir. Yine Hz. Peygamber şöyle buyurmuştur: "Allah, yaşlılara yaşı için ikram eden gençlere yaşlandıklarında hizmet ettirir." ${ }^{24}$

2. Mutasavvıfların halleri, âdâbı ve ahlâkları hususunda özel kılındıkları şey, onların sebeplerden hâlî olup tecerrütte bulunmaları ve Allah'ın gayrından alakalarını keserek Hakk'a muttasıl olmalarıdır. Bunun yanında halka karşı ahlaklı olmaları, şeriatın âdâbına sarılmaları, şeyhlere karşı hürmetli, ihvânın vaktini koruyucu olmaları, insanlardan intikam almamaları ve her vakit ve halde ilmin zahirinin gerektirdiklerine uymalarıdır.

3. Yaşadığımız şu zamanda mutasavvıfların şekline bürünüp onların libasını giyinmekle yetinen, âdâbı terk edip ruhsatlara sarılan, doğru yolun gerekliliklerini zâyî eden, şeyh ve büyüklerini küçümseyen, bu konuda bilgisiz olan avâmın kendi peşinden sürüklenmesini isteyen, hallerinin hakikatleri ile şeyhlerinin ahlak ve fiilleri doğrultusunda kendilerinden bekleneni yerine getirmeyen sözde sûfîleri görünce birkaç bölüm oluşturmak istedim. Burada ihmalkârların göz ar$\mathrm{d}_{1}$ ettikleri şeyhlere duyulması gereken saygınlık usullerini ve Allah'ın muvaffak kıldığı kimselere teşekkür edebilsinler diye zikredeceğim. Allah Teâlâ, sahâbîleri Hz. Peygamber'i tazim etmeleri ve ona saygida kusur etmemeleri hususunda muhatap alarak şöyle buyurmuştur: "Ey iman edenler! Seslerinizi peygamberin sesinden fazla çıkarmayın, birbirinize bağırdığınız gibi ona bağırmayın; sonra farkında olmadan amelleriniz boşa gider." (Hucurât/2). Yeryüzündeki velîler; resûl ve nebilerin halifeleridir. Haliyle onlara hürmetsizlik eden kimse peygamberlere tabi olmanın rahmetinden mahrum kalır. Allah Teâla, bir kulunu Kendisine hizmete layık görürse onu Hz. Peygamber'e saygılı olmakla rızıklandırır. Hz. Peygamber'e saygılı olmanın şartı ise onun halifeleri olan ümmetinin veli kulları ile Rabbânî âlimlerine hürmet etmek ve onların âdâbı ile edeplenip ahlâkı ile ahlaklanmaktır. Böylece o kimselerin nazar ve şefkatlerinin bereketlerine mülhak olurlar. Akabinde Hz. Peygamber'e olan hürmeti bilme mertebesine yükselir. Daha sonra ise efendisine hizmet etmekle vaktini en güzel şekilde korumaya

23 Tirmizî, hadisi aynı ibârelerle Enes b. Mâlik’ten rivayetle tahrîc etmiştir. Ebû İsa Muhammed b. İsa b. Sevre et-Tirmizî, el-Câmi'u'ṣ-șaḥịh = Sünenü't-Tirmizî, thk. Ahmed Muhammed Şakir (Kahire: Mustafa el-Bâbî el-Halebî, 1978/1398), “Kitâbü'l-Birr ve's-sıla”, 2043. Ahmed b. Hanbel de el-Müsned'inde aynı şekilde rivayet etmiştir. Ebû Abdullah Ahmed b. Muhammed b. Hanbel eş-Şeybânî, Müsnedü'l-İmâm Aḥmed b. Hanbel, thk. Şuayb el-Arnaut - Adil Mürşid (Beyrut: Müessesetü'r-Risâle, 1998), 11/644 (No. 7073). Sülemî daha önce "Kitâbu âdâbi's-suhbe"de aynı hadisi zikretmiştir. bk. Mecmû‘a-i Âsâr-ı Ebû 'Abdirrahmân es-Sülemî, 2/115.

24 Tirmizî, Enes b. Mâlik’ten rivayetle şu lafızlarla tahrîc etmiştir. "Bir genç, yaşlı birine yaşından dolayı ne ikramda bulunmuşsa Allah hepsini yaşlanınca kendisine dönmek üzere kayıt altına alır." Tirmizî, “Kitâbü'l-Birr ve's-sıla”, 2023. 
muvaffak olur. Fudayl b. İyâz ${ }^{25}$ [ö. 187/803] şöyle söylemiştir: "K1yamet alametlerinden biri küçüklerin kalplerinden büyüklerin saygısının kaldırılmasıdır. Böylece onlara uymayıp yollarından gitmezler." Serî es-Sekatî́2 [ö. 251/865] de şöyle söylemiştir: "Kulun kalbinde imanın yer edinmesi velilere karşı hürmeti beraberinde getirir." Abbâs b. Atầ ${ }^{27}$ [0̈. 309/921] şöyle söylemektedir: "Kul, Allah'ın haklarına riayet etmek ve Allah'ın veli kullarına hizmet etmek olmak üzere iki halden dolayı sorumludur. Kimin kalbinden velilere duyulan saygı zail olursa onun gözünde Allah'ın (a.c.) hukukuna karşı olan ihtiram da değersizleşir." Cüneyd-i Bağdâdî28 [ö. 297/909] şöyle söylemiştir: "Allah'a saygı duyup kullarına hürmet göstermemek münâfıklığın alametidir.” Ebu Abdullah b. el-Cellân (ö. 306/918) şöyle söyler: "Kula, Allah'ı bilip emirlerini yerine getirmekten sonra en gerekli şey kendisine Allah'ı bilmenin yollarını öğreten kimselere saygı duymaktır. Bu kimseler Allah'ın veli ve sâfî kullarıdır." İbrahim el-Havvâs ${ }^{30}$ [ö. 291/904] şöyle söylemiştir: “Kul, Allah'ın veli ve dostlarına hizmet etmeden Allah'a yapılan hizmetin tadını alamaz. Hizmetinin bereketi ile Mevlâ'sına hizmet etmenin zevkine vardırılır." Adamın biri "Şeyhlerimize hürmet ve hizmet etmenin bize faydası nedir?" diye sorunca Yusuf b. Hüseyin ${ }^{31}$ [ö. 304/916] şöyle

25 Fudayl b. İyâz b. Mesud b. Bişr el-Yerbûî, Horasan'ın Merv şehrinden olup Kundin denilen bir köyündendir. Sufîlerin büyük âlimlerinden biridir. Sülemî'nin Țabakāât'ında yer verdiği ilk isimdir. Ebû Abdurrahman Muhammed b. Hüseyin es-Sülemî, Ṭabaḳātü’ṣ-șûfiyye, thk. Nureddin eş-Şerîbe (Kahire: Mektebetü'l-Hancî, 1969), 7-14.

26 Serî b. el-Muğallis es-Sekatî, Cüneyd'in hem dayısı hem de hocası olup Marûf el-Kerhî'nin sohbetinde bulunduğu söylenmiştir. O, Bağdat'ta tevhid lisanı ve hallerin hakikati hususunda konuşan ilk kişidir. Aynı zamanda Bağdatlıların imamı olup kendi döneminde onların şeyhliğini yapmıştır. Sülemî, Tabakātü'ṣ-ṣ̂fiyye, 15-26.

27 Ahmed b. Muhammed b. Sehl b. Atâ el-Âdemî, sûfîlerin alim ve önde gelenlerindendir. Onun Kur'an'ı anlamada kendine mahsus bir kavrayışı vardır. İbrahim el-Mâristânî, Cüneyd b. Muhammed ve onların da ötesinde nice şeyhin sohbetinde bulunmuştur. Ebû Saîd el-Harrâz, onun durumuna sayg1 gösterirdi. Sülemî, Tabakātü'ṣ-ṣ̂fiyye, 265-272.

28 Ebü'l-Kāsım el-Cüneyd b. Muhammed, herkesin zikrettiği üzere sûfîlerin imamlarından ve önde gelenlerindendir. Şeyhu't-tâife (Sûfîlerin İmamı) olarak meşhurdur. Sülemî, Ṭabakātü’ṣ-ṣûfiyye, 155163.

29 Ahmed b. Yahya Bağdat asıllıdır. Dımaşk ve Remle'de ikamet etmiştir. Şam bölgesinin önde gelen şeyhlerindendir. Babası Ebû Yahya el-Cellâ, Ebû Türâb en-Nahşebî, Zünnûn el-Misrî ve Ebû Ubeyd el-Busrî̀nin sohbetinde bulunup Muhammed b. Davud ed-Dükkîye hocalık yapmıştır. Sülemî dedesi İbn Nüceyd'den şu rivayette bulunmaktadır: "Dünya üzerinde üç sûfî imam vardır ve bunların dördüncüsü yoktur. Bunlar Bağdat'ta Cüneyd, Nişabur'da Ebû Osman ve Şam'da Ebû Abdullah b. Cellâ şeklindedir. Sülemî, Țabakātü’ṣ-ṣ̂ufiyye, 176-179.

30 Ebû İshak İbrahim b. Ahmed b. İsmail, tevekkül yolunda seyredenlerdendir. Yaşadığı dönemin yegâne şeyhidir. Cüneyd-i Bağdâdî ile Ebu'l-Hüseyin en-Nûrî’nin akranıdır. Țabaḳātü'ș-ṣûfiyye, 283287.

31 Ebû Yakub Yusuf b. el-Hüseyin er-Râzî, kendi zamanında Rey ve Cibâl bölgesinin şeyhidir. Makamı ve yapmacıklığ1 terk edip samimiyeti hâl edinmekte yegânedir. Zünnûn el-Mısrî ve Ebû Türâb en- 
cevaplamıştır: “Zünnûn el-Misrî’ye ${ }^{32}$ [ö. 245/859] bu sorulunca şöyle söylemişti: "Sana Mevlâ'nı tanıtan ve hizmetinde bulunmanı sağlayan kişiye hizmetçi olman onun senin üzerindeki hakkıdır. Aşağıda olanı zâyî etmekle yukarıdaki rütbeye ulaşamazsın." Yusuf bir keresinde Zünnûn'un kendisine şöyle dediğini aktarmıştır: "Allah Teâla, veli kullarının heybelerine sırlarından bir sır koymuştur. $\mathrm{Bu}$ sırrı müşâhede edemeyen kalbinin körlüğünden görememiştir. Fakat müşâhede edip de buna saygı göstermeyen kimse bunu dininin noksanlığından yapmıştır." Ebû Hafs en-Neysâbûrî33 [ö. 260/874] şöyle söylemiştir: "Kişinin; doğru düzgün olmaları şartıyla avâmın, sohbetlerinin güzel olması şartıyla sâlihlerin, ne kast ettiklerini anlama şartı ile hükemânın, saygı ve hürmet göstermesi şartıyla veli ve büyüklerin sohbetinde bulunması gerekmektedir." Ebu Abdullah en-Nibâcî̀ ${ }^{34}$ ashabının birine şöyle söylemiştir: "Allah ile yaşamadı̆̆ın gibi Allah ile yaşayan birinin de sohbetinde bulunmuyorsan peki ne zaman Allah'la dirileceksin!” Ebû Amr ez-Züccâcî35 [ö. 348/959] şöyle söylemiştir: "Diri birini görmeden nasıl yaşıyorsunuz?"

4. Şeyhlerin sırlarını muhafaza etmek onlara hürmet etmenin ve sohbetinde bulunmanın âdâbındandır. Onların sırları, dinleyenlerin inkâra düşüp helâk olmamaları için ancak dinleyen kimselerin kalplerinin kabul edebileceği ölçüde fâş edilip anlatılabilir. Tasavvuf yolu ve inancına muhalif olanlarla sohbeti kesmek onlara duyulması gereken saygılardandır. Dolayısıyla kişi, şeyhlerle olan münasebetlerinde iradesini doğru hâle getirdikten sonra onlarla edep üzere sohbet edebilir. Ardından şeyhlerin, bildiği yahut bilmediği hâl, söz, fiil ve hare-

Nahşebî'nin sohbetinde bulunmuş, bazı seferlerde Ebû Saîd el-Harrâz'a refakat etmiştir. Âlim ve mütedeyyin bir kişiliğe sahiptir. Sülemî, Țabakātü’ṣ-ṣ̂fiyye, 185-191.

32 Ebü'l-Fudayl Zünnûn b. İbrahim el-Misrî, tasavvuf ilminin ilk şeyhlerinden ve önde gelenlerindendir. Sülemî, Țabakātü'ṣ-ṣ̂ufiyye, 15-26.

33 Amr b. Seleme en-Neysâbûrî, Abdullah b. Mehdî el-Ubeyveydî ve Ali en-Nasrâbâzînin sohbetinde bulunmuş ve Ahmed b. Hadraveyh el-Belhî ile seyahatte etmiştir. İmam ve önde gelenlerdendir. Şah Şucâ el-Kirmânî, Ebû Osman el-Hîrî ve Saîd b. İsmail ona bağlanmışlardır. Haddâd ismi ile meşhurdur. Sülemî, Ṭabakātü'ṣ-șûfiyye, 115-122; Mütehakkiklerden olup fütüvvette ve mürüvvette kemale ermiştir. Tanınan Nişaburlular arasında bu vasıflarla temeyyüz etmiştir. Ebû Nuaym Ahmed b. Abdullah b. İshak el-i̇sfahânî, Hilyetü̉l-evliyâ' ve țabakātü'l-așfiyâ’' (Kahire: Mektebetü'l-Hancî, ts.), $10 / 229$.

34 Ebû Abdullah Saîd b. Yezîd, Allah'ın salih kullarındandır. Ahmed b. Ebi'l-Havârî ed-Dımaşkī ve birçok kişi kendisinden birtakım hikâye ve haller aktarmışlardır. Sülemî, Țabakâatü’ṣ-ṣ̂ffiyye, 98-99.

35 Muhammed b. İbrahim b. Yusuf b. Muhammed Nişabur kökenlidir. Ebû Osman, Cüneyd, Nûrî, Ruveym ve İbrahim el-Havvâs'ın sohbetinde bulunmuştur. Mekke'ye gidip orada ikamet ettikten sonra oranın şeyhi ve en önde geleni olmuştur. Sülemî kendisi için şöyle söylemektedir: Dedemin -Allah rahmet eylesin- şöyle dediğini işittim: "Ben Mekke'deyken el-Kettânî, en-Nehrecûrî, el-Murtaiş ve diğer şeyhler de orada idi. Hepsi bir halka oluşturmuştu ve halkanın başında da Ebû Amr bulunmaktaydı. Bir konu hakkında bir şey konuştuklarında hepsi konuşulan konu hakkında Ebû Amr'ın ne dediğine dönüp bakardı." Sülemî, Țabaḳātü’ș-ș̂fiyye, 431-433. 
ketlerini inkâr etmemelidir. Sâlik, sadece bir şeyi kabul etmemesi durumunda bütün gayretinin hebâ olup gideceğini, kabul etmesi durumunda kurtuluşa ereceğini ve yüz çevirmesi durumunda da helâk olacağını bilmelidir. Şeyhlerin meclisinde bulunduğunda Hakk'a muttali kılınıp sûfî ve veli kulları ile birlikte olmak suretiyle faziletlendirilir. Kişi bu durumlardan dolayı Allah'a şükreder. Kalbi, sohbetinde bulunduğu kişiye karşı hürmet duyar. Kalbinde şeyhlere ve büyüklere karşı saygının silindiği kimse ise zâhirde makbul görünse de hakikatte helâk olur. Şeyhlerin, insanların içindeki Allah'ın gözleri oldukları bilinmelidir. Allah şeyhlere diğer kullarının içindeki sırları gösterir. Böylece şeyhler, onların sırlarına tahakküm edebilir. Şeyhin, mürîdleri kabul etmesi ve mürîdlerin şeyhlere karşı duydukları ihtiram bu inanç sayesindedir. Bir kimsenin kalbinden şeyhlere duyulan hürmetin ilgisizliği Hz. Peygamber'e duyulan saygısının değersizleşmesi ile gerçekleşir. Kişinin bu basite alma tavrı yüzünden Allah'a (c.c.) olan saygının değersizleştirilmesini de beraberinde getirir. Bu raddenin getirdiği cezasının alameti, kişinin kalbinden evliyâya olan hürmetin çıkarılmasıdır. Nitekim Hz. Peygamber, bir kutsî hadiste şöyle buyurmaktadır: "Kim benim veli bir kulumu küçümserse bana savaş açmış olur." ${ }^{36}$ Zira velilerin saygınlığını küçümseyenler Hz. Peygamber'in, Hz. Peygamber'in saygınlığını küçümseyenler de Allah'ın saygınlığını, zikrini ve emirlerini küçümseyerek helâk olur.

5. İşin özü, kişinin nefsini görmesi, kendini sevmesi, lider olmak istemesi ve insanlardan kabul görme arzusu ile kendini olmadığı bir hale ulaştırma muradıdır. Hz. Peygamber'e hürmete götürecek yol olarak selefe ve büyüklere saygıyı kendine düstur edinmeyen kimse Hz. Peygamber'e hürmet makamına ulaşamaz. Hz. Peygamber'e saygı göstermenin ve ona tabi olmanın yolunu bulamayarak Hakk'a kavuşma derecesinden sâkıt olan kimse, Hz. Peygamber'e uymanın bereketinden düşüp zelil ve mahrum bir şekilde yaşar. Şeyhlerin saygınlığını küçümsemek ihvân ve sohbet arkadaşlarının saygınlığını küçümsemekten doğmaktadır. Kul, alt makamları zâyî ederek nasıl yüce mahallere ulaşabilir ki? İhvândan birini küçümseyen kimse kibrini, rezilliğini, kendini büyük görmeyi ve Allah'ın kendisine tazim edilmesini hak kıldığı küçümsemeyi izhâr eder.

6. Kulun, kendini yüceltip ihvânını alçaltması kötü olmasındandır. Hz. Peygamber şöyle buyurmuştur: "Kalbinde hardal tanesi ağırlığında kibir olan kimse cennete giremez. ${ }^{{ }^{37}}$ Allah, avâmın peşinden gelmesini isteyen ve kendi zilletini kabul

36 Uzun bir hadis cüzü olan bu ibare İbn Adî’nin el-Kâmil'inde yer almaktadır (Mütercim Notu: Adı geçen eserde ilgili hadis rivayetine rastlanmamıştır). Hadisin meşhur varyantı Buhârînnin Ebû Hureyre'den naklettiği rivayettir: "Allah şöyle buyurmuştur: 'Kim benim veli bir kuluma düşmanlık beslerse ona savaş açarım..." ("Rikâk", [6502]). İmam Şevkânî bu hadis üzerine Katru'l-velî 'alâ hadîsi'l-velî başlıklı müstakil bir kitap yazmıștır (thk. İbrahim Hallâl, Kahire, 1979).

37 İmam Müslim İbn Mesud'dan rivayet etmiştir. Ebü'l-Hüseyin Müslim b. el-Haccâc el-Kuşeyrî enNeysâbûrî, Șahihhu Müslim, thk. Muhammed Sâlih Hâşim (Beyrut: Dârü'l-Kütübi'l-İlmiyye, 1994), “Kitâbu'l-imân”, 91; Tirmizî, “Kitâbu'l-birr ve’s-sıla”, 2129; Tayâlisî, Müsned, “Kitâbu'l-edeb”, 4091; vd. 
eden kişinin ihvân ve şeyhlerine dil uzatmayı serbest bırakır. Böylece gözlerinden hayâ perdesi çekilir. Mutlu etmeksizin mutlu olur. Nitekim Allah Teâla şöyle buyurmuştur: “...Sakın şımarma! Bil ki Allah şımarıkları sevmez...” (el-Kasas/76). Zira Allah'ın kuluna yönelmesinin değeri, onun Allah'ın velilerine yönelmesi kadardır. Allah onu, diğerlerine hizmeti ölçüsünde rızıklandırır. Kul, ancak kâbil olursa makbuller derecesine ulaşabilir. Şayet kişi, şeyhin kendisine işaret ettiklerine kâbil olursa halk nezdinde makbul olur. Halk, böylece ondan gelen şeyleri kabul edip onun kabul edilmesine yardımcı olur. Bu durum kendisinin şeyhinin makbûliyetine yardım etmesine benzemektedir. Allah Teâla, heybetinin eserlerini ve muhabbetinin nurlarını ona ilkâ eder. Böylece iyiler onu severken kötüler ondan korkar ve hürmetine tazim edip hizmetinde bereketlenerek onun sohbetinde bulunurlar. Bu durum Hz. Peygamber'in işaret ettiği gibidir: "Allah bir kulunu severse Cebrail'e (a.s.) şöyle seslenir: "Allah Teâla falanca kimseyi seviyor. Böylece diğerleri de onu severler." Ardından yeryüzünde kabul görür. Onun makbûliyeti yalnızca avâm ve muaşeret ehli arasında değil, kullardan havâs olanlar arasında da gerçekleşir.

7. Kul, ihvânına ve ashabına hürmet gösterip hizmet edince bu durum beraberinde salih kimselere karşı hürmet ve sohbetin bereketini getirip velilerin kalplerinin kendisine meyletmesini sağlar. Dolayısıyla salih kimselerin hizmetinde bulunursa bunların yanında bereket ve velilerin hürmet, saygınlık ve kabuliyetlerini edinir. Böylece Hz. Muhammed Mustafa'nın sünnetine zâhirî ve bâtınî olarak uymanın bereketini kazanır. Sünnete uyması beraberinde ihlaslı olarak efendisinin hizmetinde bulunmayı sağlar ve onun hizmetinde samimi olur. Kul, efendisinin hizmetinde ihlaslı olarak bulununca Allah onu ahrâra ${ }^{38}$ hizmetkâr kılar ve böylece mürîd ve sâdıklara hizmetkâr olur. Nitekim Hz. Peygamber'in şöyle dediği rivayet edilmiştir: "Bir topluluğun efendisi, onlara hizmet edendir."39 Hâkezâ Hz. Peygamber, temsilci olarak gelen Habeşî bir gruba hizmet ederken ashabı şöyle söylemişti: "Ya Resulallah! Bu işi biz yapalım.” Hz. Peygamber ise

38 Mütercim Notu: “Arapça hürr kelimesinin çoğuludur, hürriyet sahibi olanlar, hür kişiler demektir. Dünya kayıtlarından ve nefsin kötü sıfatlarının etkisinden kurtulmuş kişiler, özgürlüğü elde etmişlerdir. Bu yüzden bunlara, ahrar yani hür kişiler denir." Ethem Cebecioğlu, Tasavvuf Terimleri ve Deyimleri Sözlüğü, "Ahrâr" (İstanbul: Ağaç Kitabevi Yayınları, 2009), 27.

39 Süyûtî el-Hâvî li'l-Fetâvînnin ikinci cüzü, "el-Fetâvîl-hadîsiyye”, Kitâbu'l-edeb ve'r-rekāik'te bu hadisi zikretmiştir. (Mütercim Notu: Muhakkikin bahsettiği bölümde ilgili hadisle irtibatlı bir bilgiye rastlanmamıştır. Ebü'l-Fazl Celaleddin Abdurrahman b. Ebî Bekr es-Süyûtî, el-Hâvî li'l-fetâvî (Beyrut: Dârü'l-Kitâbi'l-Arabî, 2000), 344-348.) Sülemî, “Kitâbu âdâbi'ṣ-șuḥbe"de Yahya b. Eksem'den aynı hadisi rivayet etmiştir. bk. Mecmû' $a$-i Âŝâr-1 Ebû 'Abdirrahmmân es-Sülemî, 2/97. Keşfü'l-hafẩ'da Aclûnî Sülemî’nin senedi ile zikredilen hadis hakkında şöyle söylemiştir: "Hadisin senedinde zayıflık ve kopukluk vardır." Ardından hadisin başka bir varyantını zikrederek durumu şöyle açıklamıştır: "Bu hadis için "Tarikin çokluğundan dolayı (sözü geçen) hadis hasen ligayrihidir." denilmiştir." Ebü’l-Fidâ İsmail b. Muhammed el-Aclûnî, Keş̧ü'l-hafầ' ve müzîlü'l-ilbâs 'amme'ştehere mine'l-ehâalîs 'alâ elsineti'nnâs, thk. Yusuf b. Mahmud Hacı Ahmed (Dımaşk: Mektebetü'l-illmi'l-Hadîs, 1424), 1/528. 
"Onlar ashabıma ikramda bulundular. Ben de onlara mükâfatta bulunmayı isterim" dedikten sonra "Bir topluluğun efendisi, onlara hizmet edendir." buyurmuştur. Hz. Peygamber bu olayda kendini ima etmiştir. Zira sözlerini mutlak olarak söyleyerek sahabeyi kendi ihvânı, ashâbı ve diğer kimselere karşı hizmet etmeleri hususunda teşvik etmek istemiştir. Kesin olarak bilinmelidir ki Müslüman kardeşine hakaret etmeyi aklına getiren kimsenin kalbini Allah karartır. Şeyhlerin hizmeti ile rızıklanıp onlara saygı gösteren üç şeyi elde eder. Bunlar dünyanın geri kalanını kerih görme, dünya malının çokluğuna buğz etme ve yarına önem vermeyi kalpten çıkarmaktır.

8. Bilmelisin ki veliler ve büyüklerle olan sohbet tehlike ve engelleri beraberinde getirir. Sohbete katılacak kişi Hz. Ebû Bekir'in Hz. Peygamber'le olan sohbeti gibi bir sohbette bulunmalıdır. Nitekim Hz. Ebû Bekir ne din ne de dünya hususunda Hz. Peygamber'e muhalefet etmiştir. Bundan dolayı Allah Teâla onu "sâhibihi/dostu" olarak isimlendirdi: “...Hani onlar mağaradaydılar; arkadaşına 'Tasalanma! Allah bizimle beraberdir.' diyordu...” (et-Tevbe/40).

9. Kişinin usûl ve furu'da muhalif kimselerle dostluk yapmaması sohbetin âdâbı ve kemalindendir. Nitekim furu' usûlün neticesidir ve "Falan kimse bize usûl olarak muhalefet etmiyor" sözüne kulak asmamak gerekir. Zira usûle olan muhalefet tevhidin hakikatinden çıkmak iken furu'a olan muhalefet sünnet ve âdâbı küçümsemektir. Bunun neticesinde kalp kararır, sır dağılır, ebepsizlik elinden zuhur edip gönlünde yer eder. İnsanların sohbet ile muâşereti ayırt etmeleri gerekir. Muâşeret, vakit içerisinde geçerliyken sohbette devamlılık esastır. Muâşeretin bulanıklığı muhalif kimselerle birlikte olmaktan kaynaklanmaktadır. Ebû Ali er-Rûzbârî'nin ${ }^{41}$ (ö. 322/934) Mansûr b. Abdullah'tan ${ }^{42}$ (ö. 309/922) nakille bana aktardı̆̆ı hikâye bu minvaldedir: "Muhalif kimselerle olan muâşeret zindanların en darıdır." Sohbetin bulanıklı̆̆ı ise itikadî muhalefetten doğmaktadır. Yahya b. Muaz’ın şu sözleri bu minvaldedir: "İnancı, inancına ters düşen kimsenin kalbi, kalbine muhalif olur."

10. Az konuşmak, zorunlu haller ve ihtiyaç gerektiren durumlar dişında soru sormamak şeyhlerle aynı mecliste bulunmanın âdâbındandır. Nitekim yalnızca ihtiyaç duyduğun şeyi sorduğunda, sorun karşısında şeyhin cevabındaki faydalar senin için açığa çıkar ve sen de onun bereketinin tesiri altında kalırsın. Fakat gereksiz soru sorman ilmini izhar etme isteğini ortaya koyar ve bereketi ile tesir altında kalamayacağın bir cevap aleyhine delil olur. Kişinin sohbet arkadaşının kendine olan uyumunun yanında ihtilafını bilmesi ile kendisinden ve halinden

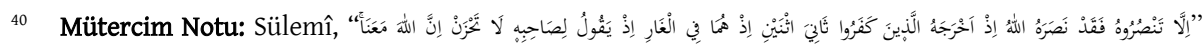
ayetinde geçen “帖” ifadesine atıfta bulunmaktadır.

41 Ahmed b. Muhammed b. el-Kāsım b. Mansûr, Bağdatlıdır. Mısır'da ikamet etmiş, oranın şeyhi olmuş ve orada vefat etmiştir. Sülemî, Țabakātü’ṣ-șûfiyye, 354-360.

42 Ebü'l-Hasan Mansûr b. Abdullah ed-Dîmitî el-İsfahânî, Sülemî onun hakkında birçok rivayette bulunmuştur. Tabakât'ta onun hakkında pek çok rivayet mevcuttur. Sülemî, Ṭabakātü'ṣ-ṣ̂ufiyye, 307-311. 
haber vermeye hâcet duymaması sohbetin sihhatindendir. Hz. Muhammed'in durumunu dostu olan Hz. Ebu Bekir'in dışında kimsenin bilmemesini nasıl görmezsin? Onun hakkında şöyle söylemişti: "Allah, kulunu dünyada ve Kendi indinde olan şeyler arasında tercih yapması hususunda muhayyer birakmıştır."43 Bu durum sohbetinin sahih ve imanın kuvvetli olmasından dolayıdır. İmam Şâfî̂ şöyle söylemiştir: "İhtiyaçlarını bilmediğin kimse, kardeşin değildir."

11. Kişinin şeyhinden mahallini ve derecesini yükseltmesini yahut kendisi ile daha fazla konuşmasını beklememesi ve riyazetlere sabır göstermesi sohbetin âdâbındandır. Bunun yanında şeyhinin kendisini ve hallerini ondan iyi bildiğini, onu terbiye ettiğini, onun dikkatini hayra yönlendirdiğini ve kısa yahut uzun süreçte ona fayda vereceğini bilmelidir. Şeyhi onu diğer ashabı arasında rifkati, ilmi yahut terbiye etmesi yönünden kayırırsa bu durumda kendini suçlamalı ve kendinden edepsizliğin ya da açgözlülüğün sâdır olduğunu düşünmelidir.

12. Şeyhlerin huzurunda himmetinin ve zihninin dağılmaması ile kişinin himmet ve havâtırını şeyhinin âdâb, ahlak, emir ve yasaklarına teksif etmesi mürîdlerin âdâbındandır. Şeyhlerin meclisinde kişinin himmeti ve havâtırı dağılırsa terbiye ve ilim tahsil etme derecesinden düşer.

13. Şeyhlerin meclisinde (sanki zorla oturuyormuşçasına) onların sabırlarını zorlayacak ölçüde bulunulmamalıdır. Aksine onların meclisinde şereflenmek ve hizmetleri ile bereketlenmek için bulunulmalıdır. Onların meclisinde bulunmanın âdâbı, şeyhin yaptığını değil emrettiğini yapmaktır. Mürîd, yalnızca dinleyen kişinin kalbinin kabullenebileceği haberleri aktarabilir. Zira şeyhlerin bazı sırları vardır ki mürîdler buna muttali olamaz. Hal böyle olunca bunu kabul etmeyen münkir helâk olur. Tâbi olan kişi, peşinden gidilenin makamına ancak belli bir süre sonra ulaşabilir. Hz. Peygamber' in şöyle dediğini görmez misin? "Beni namaz kılarken nasıl görüyorsanız siz de öyle namaz kılın." Yoksa "Benim gibi namaz kılın.” dememiştir. Hz. Peygamber sahabenin, halini yerine getirmekten aciz kalacağını bilmekteydi. Böylece onları zâhir olan fiiline yönlendirdi.

14. Mürîd, kendisine mecliste sükût âdâbı yerleşinceye değin şeyhin huzurunda sükûtla başlar. Ardından sükûtun âdâbı mürîde yerleşince ve şeyh onun ehil olduğunu görünce mürîd hizmete geçer. Hizmetin âdâbı oturur, gereklerini yerine getirir ve hizmet ederse şeyhi onun konuşmasını ister yahut konuşmayı emrederse konuşur. Sonra gerekli olacak kadar konuşur.

43 İmam Buhârî Ebû Sâid el-Hudrî'den rivayetle şöyle nakletmiş̧ir: "Allah kulunu dünya nimetlerinden dilediği kadar vermek ve Kendi indinde olanı vermek hususunda muhayyer bırakmıştır. Sen, Allah'ın katında olanı seç!" Ebû Abdullah Muhammed b. İsmail b. İbrahim el-Cu'fî el-Buhârî, Șahịhư'lBuhârî, "Kitâbu Menâkibil'-Ensâr", 63; Tirmizî, "Kitâbu Menâkibi Ebî Bekr es-Sıddîk", 45; İmam Mâlik, el-Muvațta'da İmam Muhammed b. el-Hüseyin'den rivayetle aktarmıştır. Osman b. Yackûb el-Kemâhî, el-Müheyye' fí keşfi esrâri'l-Muvatța', thk. Ahmed Ali (Kahire: Dâru'l-Hadis, 2005), 4/305. 
15. Mürîd, şeyhine karşı samimi olup onu tazim etme hususunda himmetini tashih etmeye çabalar. Şayet mürîd bunu gerçekleştirirse işaret ilminde ve hikmetli olma noktasında bu durum ona kâfi gelir. Şeyhlerin hizmetinde ve hürmetinde bulunan kimseye Allah Teâla korku ve rağbet, tövbede israr, kanaatte hırs, endişede sabır, gazapta rıza, kibirde tevazu, zillette izzet, şekte yakîn, inkârda marifet, redde kabûl, zayıflıkta kuvvet, dünya sevgisi ve ehlinden istiğna, harekette sükûn, açgözlülükte durgunluk verir. Sıfat ve hallerinden fenaya erip Hak ile baki olma, tembellikten çalışkanlığa, gafletten uyanıklığa, tedbirden tefvize, isteğini elde edememekten muvaffakiyete, buğzdan muhabbete, himmetin dağılmasından cem'ine geçmeyi nasip eder. Ardından bu minval üzere sonsuza kadar devam eder.

16. Bunların hepsi şeyhin hizmetinde bulunulması ve ona karşı saygıda kusur edilmemesi gerektiği inancının sıhhatli olması ile gerçekleşir. Büyüklerin terbiyesinde bulunmanın bereketinin dışa vurduğu eserlerin görülmemesi kişinin içinin bozukluğuna delalet eder. Hakîmu'l-vakt Ebû Hafs şöyle söylemektedir: "Zâhirdeki güzel edep, bâtındaki güzel edebin göstergesidir" 44 Allah Teâla da şöyle buyurmuştur: "Evet, bu böyledir. Kim Allah'a ait nişânelere saygll davranirsa, bu kalplerin takvâlı olmasındandır." (el-Hacc/32). Şiarların zahirine tazimde bulunmak kalpleri bâtınen kuvvetli kılar. Böylece sana şunu gösterir: Zâhirî olarak görülen bereketler bâtınî bereketlerden; batınî nurlar da zâhirin eserlerinden kaynaklanmaktadır. Bundan dolayı hükemânın bir kısmı şöyle söylemiştir: "Sırrı duru olanın dışı aydınlanır." Nasihatte bulunan şeyhin sohbetinin edeplendirmediği kimse müşahededen razı olamaz. Kendisinde zahirî olarak mutluluğun eserleri ortaya çıkmışsa da hakikatte iflah olmaz. Aldanış ve istidrac mahallinde bulunur. Hz. Peygamber'in "Beni görene müjdeler olsun!" ${ }^{5}$ buyruğunu görmez misin? Bunun manası şöyledir: Beni görmenin bereketinin tesiri altında kalan, âdâbımla edeplenen, ahlakımla ahlaklanan kimsenin edebi; Hakk'ın edebi, ahlakı Allah'ın kendisi ile bürünülebileceğini vasıfladığı ahlaktır. Sahih olmasa dahi Hz. Peygamber'den rivayet edilen bir hadiste şöyle buyrulmaktadır: "Beni Allah tedip etti. Edebim ne de güzeldir." ${ }^{46}$ Allah, Hz. Peygamber'in ahlakını şöyle vas-

${ }^{44}$ Bu rivayet Ṭabaḳāt'ta zikredilmiştir. Ebû Hafs sözünü şöyle tamamlamaktadır: “Zira Hz. Peygamber (s.a.v.) şöyle buyurmaktadır: 'Bir kimsenin kalbi huzur içinde olursa uzuvları da huzur içinde olur.” Sülemî, Țabakātü'ș-ṣ̂fiyye, 122.

45 Tayâlisî Müsned'inde aynı hadisi şu lafızlarla zikretmiştir: "Beni görüp de iman edene müjdeler olsun! Fakat beni görmeyip de iman edene yedi kere müjdeler olsun!” Ebû Dâvûd Süleyman b. Dâvûd b. Cârûd et-Tayâlisî, Müsnedu Ebî Dâvûd eț-Ṭayâlisî, thk. Muhammed b. Abdulhasan et-Türkî (Cize: Dârü'l-Hicr, 1999), 3/379. Diğer rivayet ise şöyledir: "Beni görüp de iman edene müjdeler olsun! Fakat beni görmeyip de iman edene müjdeler, müjdeler ve müjdeler olsun!”. Tayâlisî, Müsned, 2/452.

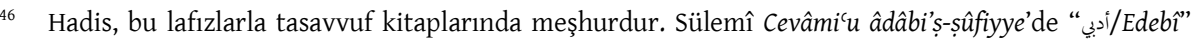
lafzını, "Cevâmi'u âdâbi'ṣ-șûfiyye”, Mecmû' a-i Âsâr-ı Ebû 'Abdirrahmân es-Sülemî, 1/343; Kitâbu Âdâbi'ș-

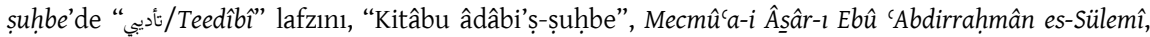
2/126; kullanmıştır. Aclûnî bu hadis için şöyle söylemiştir: “Askerî, Hz. Ali'den (r.a.) rivayetle aktar- 
fetmektedir: "Muhakkak ki sen büyük bir ahlak üzeresin." (Kalem/4). Hakk'tan ayrılmayan ve O'ndan başkası ile meşgul olmayan, zahirde insanların şekillerinde olup bâtınen Hakk'ın hakikati ile tahakkuk eden bir ahlaktan daha büyük bir ahlak olabilir mi? Onu tesiri altında bırakan bir hal yoktur. Zira o, hepsinden üstün, Hakkın müşahedesi ve komşuluğu ile doludur.

17. Şeyh ve büyüklerin âdâbı, mürîdin edebinin neticesi; onların ahlakı ise onun ahlakına tabidir. Onların ahlakına uyup âdâbı ile edeplenmek Hz. Peygamber'in ahlakı ile ahlaklanıp âdâbı ile edeplenen kişi gibidir. Kul, üst derecedeki nura erişip de ne zaman alt derecedeki nuru yitirebilir ki? Nitekim şeyhlerinin haklarını zâyî eden kişi ne zaman Hz. Peygamber'e hakiki anlamda hürmet gösterebilir ki? Hz. Peygamber'e hürmetsizlik edip de marifet ve muhabbet iddiasında ne zaman bulunabilir? Allah Teâla şöyle buyurmuştur: "De ki: Ĕger Allah'ı seviyorsanız bana uyun ki Allah da sizi sevsin..." (Âl-i İmrân/31). Aynı şekilde şeyhlere hürmet göstermeden Hz. Peygamber'e; ihvâna karşı hoş sohbette bulunmayıp, cömertlik göstermeyip ve hürmet etmeden de şeyhlere ihtiram etmek mümkün değildir. Allah Teâla, Hz. Peygamber'in ashabını şu sözleriyle edeplendirmiştir: "Odaların dışından sana seslenenlerin çoğu kuşkusuz düşünemiyorlar. Sen yanlarına çıkıncaya kadar sabredip bekleselerdi elbette kendileri için daha iyi olacaktı. Yine de Allah çok bağışlayıcı, çok esirgeyicidir." (Hucurât-45). Zira onlar, Hz. Peygamber'in kapısını tırnakları ile çalarlardı.

18. Şeyhlere hizmet ve hürmet edip ihvâna sohbette bulunmak isteyen kimse ayırt etmeksizin tüm fakirlere ikramda bulunup insanlara karşı kendini büyük görmeyi ve nefsi için onlardan intikam almayı bırakmalıdır. Fakirleri küçük görmek ve insanlara aşırı tazimde bulunmak belâların kaynağıdır. Allah; ihvânın hizmetinde bulunmaya, şeyhlere saygıda kusur etmemeye ve her iki makamın da âdâbının gereğini yapmaya muvaffak kıldığı kulunu, şeyhlerin vardığı noktaya ulaştırıp onları rızıklandırdığı şeyle rızıklandırır.

19. Şeyh ve büyüklerin ihvân, ashâb ve evlatlarına verdikleri sözleri yerine getirmeleri sohbetin gereklerindendir. Nitekim yaşlı bir kadın Hz. Peygamber'in huzuruna varmış ve Hz. Peygamber ona saygı gösterip kendi yerine oturtmuştu. Ona bunun sebebi sorulunca şöyle buyurmuştur: "O kadın, Hatice'nin zamanında da gelirdi. Ahde vefa imandandır." ${ }^{47}$ Şeyhlerin âdâbıyla edeplenip onlara karş1 saygıda kusur etmeyen kimse, kendisine uyularak mürîdlerin istifade ettiği bir imam olur. Kendinden geçen kişi ise hem helâk olur hem helâk eder.

mıştır... Tirmizî Sünen'inde hadisi tevsik etmiştir. Esmâî, Ebû Amr b. Alâ ve Ezherî hadis üzerine konuşmuşlardır. Ebü’l-Fazl b. Nâsır hadisi sahih kabul edip Hz. Peygamberimizin mucizeleri arasında saymıştır." Aclûnî, Keşfü'l-hafâa', 84.

47 el-Hâkim en-Neysâbûrî el-Müstedrek'inde bu hadisi rivayet ederek şöyle söylemiştir: "Ṣahịhayn'ın şartlarına göre sahih bir hadistir." "İmân”, 46 [10/16]. Sülemî daha önce "Kitâbu Âdâbi’ṣ-ṣuhbe"de aynı hadisi zikretmiştir; bk. Mecmû'a-i Âsâr-1 Ebû 'Abdirrahmân es-Sülemî, 2/73. 
20. Tasavvufun temeli iki şeydir. Bunlar nefsi tahkir etmek ve Müslümanların saygınlığına tazimde bulunmak. Ardından dünyayı tahkir edip Allah'ın yasaklarına saygı göstermek, Allah'ın yasaklarına saygı gösterirken kalpten dünyaya olan saygıyı silmek gelir. Fakat sebepleri terk eden kişinin Müsebbib'e ulaşamayacağını da bilmesi gerekir. Allah'ın yücelttiğini küçümseyen kimsenin gönlünde, Allah'ın yüceliği ve O'nun azameti yer edinmez. Halka gösteriş yapmak ve onlara meclislerde liderlik etmek için şeyhlerin sohbetinde bulunup sözlerini işiten kimseyi bu durum helâk eder ve ihtiram edilmesi gereken şeylere karşı saygısızlıklarından dolayı zındıklar arasına sokar. Bundan dolayı şöyle söylenmiştir: "Kendi nefsi için vaaz dinleyip, onu kendine saklayan kimse ondan istifade eder ve kim ki başkası için dinleyip onu yayarsa helâk olur." İhvânın sohbetinden lezzet almayan şeyhin âdâbı ile edeplenemez. Onların âdâbı ile edeplenmeyen sohbetin bereketine ulaşamaz. Sohbetin bereketine ulaşamayan farzların âdâbına, sünnete tâbi olmaya ve bunların bereketine eremez. Farzların âdâbı ve sünnete ittibâdan ayrı düşen kimse marifet makamına ulaşamayıp aldanma çölüne dalar. Böylece müşâhedenin bereketi, mütalaa edilmiş hayat, hallerden faydalanma ve hallerin baş göstermesi onda zuhur etmez. Büyüklenmekten kaynaklanan iddiaya yönelir ve kendisinden hakikat nurlarının manalarının aslı soyutlanır. Şeyhlerin hizmetinde bulunan kimsenin onlara yaptığı hizmetin karşılığını faydalanacağı bir nimet yahut hoş karşılamayacağı bir külfet olarak beklememesi gerekir. Böylece yaptığ iş, sohbetin ve hizmet etmenin bereketi ile hakikat yoluna ulaşabilmek için başka hiçbir şeyle uğraşmaksızın yalnızca şeyhe hizmet etmek olur. Zira tarikatın gereği nasihat eden hakîm birinin irşat edip yol göstermesi ile arzu edilen yere varmaktır. Çünkü mürşid, onu en yakın ve en kolay olan yola yönlendirip vakitleri hakkında -şayet kendisine herhangi bir şey ârız olmuşsa- mülahazalarda bulunur. Ardından onu varılacak yere ve doğru yola döndürür. "Sebepleri görmek Müsebbib'den kopmaktır." diyen kimse hata eder. Zira Allah'ın yücelttiği şeyi yüceltmek vaciptir. Hal böyle olunca sebeplere karşı tazimde bulunmak -şayet Allah onlara tazim etmişse- saygı duymaktır. Böylece O'ndan olan her şey yücelmiş olur. Eşyayı küçük görmek, onlarla olan bağlantımız cihetindendir ve küçümseme mecazen gerçekleşir. Yoksa eşya Hak tarafından geldiği için illetsiz; kul olması bakımından illetlidir.

21. Müridin irade ve halleri dönüşürken, terbiye ve ahlaklanma sürecinde, riyazet ve mücahede yolu boyunca şeyhe hizmet etmeye devam etmesi gereklidir. Hallerden fenaya erişir, marifet derecelerine ulaşır ve marifet derecelerinden Marûf'u müşahedeye yükselirse sırrı ile maksuttaki mecraları mütalaa eder. Zira bunların hepsi şeyhe râcidir. Sebepler de tazim ve hürmet yolu olmaksızın perdedir. Nitekim şeyhler O'na yönlendirip O'nun için terbiye ederler. Cüneyd-i Bağdâdî'nin elinde tespih gördüklerinde ona şöyle söylemeleri bu kabildendir: "Ey Ebâ Kâsım! Bulunduğun yüce makama ve şerefli haline rağmen elinde tespihle mi geziyorsun?" Cüneyd "Evet, onun sebebi ile vardığımız yere ulaştık. Onu asla bırakmayız." Cüneyd'in rüyada görüldü̆̆ü ve kendisine şöyle denildiği rivayet edilmiştir: "Allah sana nasıl muamelede bulundu?” Cüneyd şöyle cevap 
vermiştir: "işaretler savruldu, ibâreler yok oldu, şekiller bir kenara atıldı, ilimler kayboldu ve sadece seher vakti kılmış olduğumuz iki rekât namaz fayda sağlad." Cüneyd, burada sebepleri söylemiştir ki iddia sahibi kimse, Allah'ın yol gösterici ve meşale kıldığı sebepleri küçümseyip aldanmasın. Vesilelere tazim edenler bereketleri ile dirilirler. Nitekim onlar, nefisleri ve ruhları ile değil Allah ile diridirler. İnsanlar Hay olanın müşahedesi olmaksızın ölüdürler. Ezelî olan Hayy'a ve hakiki hayata ulaşmaya yol gösteren yaşamın bereketi ile feyz elde eder. Allah Teâla, yarattıkları arasından insanları diriltti. İnsanları yaşam ile onurlandırana ve kendisi için yaratılana (Allah'a) sebep kıldı. Kur'an-1 Kerim'de şöyle buyurmuştur: "Size hayat veren, sonra sizi öldürecek ve sonra sizi diriltecek olan da O'dur...” (Hacc/66). Ayetin manası şöyledir: Benimle dirilip vasıflarınızdan arınmanız için sizi sizinle diriltmek için dirilttim ve ardından sizi sizden ve suretlerinizden (sıyırarak) öldürdüm. Bu hale varıp da müşahedede bulunanınız beni müşahede etsin. Sizden dirilen kimse kendiniz olmaksızın başka bir şeyle dirilir. Zira siz hakikatte Benimlesiniz ve Benimsiniz. Sizin sıfatlarınız sizden arındırılmışken Benim sıfatlarımın bereketi sizin üzerinizdedir. Siz, siz olmaksızın Benimlesiniz. Daha da ötesi siz yoksunuz, celal ve kerem sahibi ve daimi Hay olan Ben varım.

22. Şeyh ve büyüklere tazim ve ihtiram göstermek, onların âdâbı ile edeplenmek, ahlakları ile ahlaklanmak, saygıda kusur etmemenin yanında onların emirlerine muhalefet eden ve onları küçümseyenlerin şekâvetini göstermek için tertip ettiğim bu başlıklar altındaki bölümleri açıkladım. Allah Teâla'dan aldananlar sınıfından olmamamız için anlattıklarımıza bizi muvaffak kılmasını, Müslümanlara karşı saygıyı gönlümüzden alıkoymamasını, onların değerlerini bilmemizi, fazlı ve geniş rahmeti ile niyaz ederim. Buna kâdir olup yerine getirecek olan yalnızca O'dur.

23. Hamd, âlemlerin Rabbi olan Allah'adır. Efendimiz Hz. Muhammed'e, âline ve ashâbına salât ve selam olsun.

\section{Edebü mücâleseti'l-meşâyiḩ ve ḥfẓi ḥurumâtihim Risâlesinin Değerlendirilmesi}

Maksadı "Allah'in ahlakıyla ahlaklanmak" olan tasavvuf ilminde bu gâye, sohbet ile hâsıl edilmek istenmiştir. Fakat sohbetin âdâbı nasıl elde edilecektir? Sülemî, şeyhin huzurundaki sohbet âdâbından önce sâlikin edinmesi gereken ferdî âdâbları zikrederek sûfîlerin neden âdâba riayet etmeleri gerektiğini söyler. Ferdî âdâb; mâsivâdan tecerrüt edilip her şeyin yalnızca Allah'tan dilenmesi gerektiği fikriyle itikâdî âdâb, ruhsatların terki ile birlikte ibâdete sarılarak amelî âdâb ve şeyh, ihvân, mürîd ve halk ile iyi geçinilmesi hususundaki muâşeret âdâbı şeklindedir. Yazarın risâleyi yazmasındaki bir diğer sâik de sûfî libasına bürünmüş fakat bu yolu zâyi eden kimselere karşı mutasavvıfları uyarma arzusudur. Sülemî, bu hususta Allah tarafından tedip edilen Hz. Peygamber'in örnek kişiliğine vurgu yaparak risâlesine başlamaktadır. Velilerin yaşantı ve sünnete bağlılıkları hasebiyle $\mathrm{Hz}$. Peygamber'in vârisleri olmalarına işaret eden Sülemî, onların yolundan yürümeyi 
Hz. Peygamber'in yolunu tutmaya benzetmektedir. Sülemî, deyim yerindeyse velileri/şeyhleri Hz. Peygamber'in makamına; mürîd ve sâlikleri de ashâbın yerinde tasavvur etmektedir. Böylece Hz. Peygamber'den sâdır olup silsileler halinde aktarılan âdâb ve ahlak, tasavvuf yoluyla önce şeyhlere ardından da mürîdlere tevârüs etmektedir.

Sülemî, sohbet ve sohbet âdâbının gerekliliğini beyan ettikten sonra sohbet âdâbının mahiyeti hakkında bilgi vermeye koyulur. Sohbetin âdâbını şeyh, mürîd ve ihvânın kendi arasındaki münasebetleri çerçevesinde değerlendiren Sülemî, her grubun üzerine düşen birtakım yükümlülüklerin olduğunu ve bu kimselerin karş1lıklı bir sorumluluk içerisinde olduklarını belirtir. Bu minvalde mürîde şeyhin sırrını korumak, bu sırları nâdâna anlatmamak, şeyh ve ihvâna hizmet etmek, ihvânına karşı îsârda bulunmak gibi görevler düşerken; şeyhe için de kibirden uzak durmak, mürîdlerini birbirinden kayırmamak, onlarla ilgili durumlara vâkıf olup savrulmalarını engellemek gibi birçok vazife sayılmaktadır. Sülemî sûfîleri içeridekilere karşı nasıl bir âdâbı benimsemeleri gerektiği hususunda uyarırken onları dışarıdakilere karşı da uyarmaktadır. Tasavvuf yolundaki sâlikleri, sûfî usûl ve furû'una uymayan kimselere karşı temkinli olmaya davet ederek şöyle söyler: "Kişinin usûl ve furû'da muhalif kimselerle dostluk yapmaması sohbetin âdâbı ve kemalindendir." ${ }^{48}$ Müellif bu ikâzda bulunurken dişarıdaki kişinin sûfîlerin sırrına muttali olamayıp helâk olabileceğinden çekinmektedir.

Şeyhin hizmetinde bulunup riyâzet ve mücahedede bulunan kişi sohbetin maksadına ulaşır. Böylece mürîd fenaya erişir, marifet derecesine varır ve en nihâyetinde Marûf'u müşâhede eder. Bu noktaya ulaşan mürîd, şeyhin de bir perde olduğunu, aslında her şeyin Allah'la olup Allah'ın olduğunu anlar. Akabinde mürîdin kendi de aradan çıkar ve geriye yalnızca Allah kalır. Sülemî bu durumu ise şöyle açıklar: "Siz, siz olmaksızın Benimlesiniz. Daha da ötesi siz yoksunuz, celal ve kerem sahibi ve daimi Hay olan Ben varım." ${ }^{49}$ Sâlik böylece Allah'ın sıfatları ile vasıflanır. Sülemî’nin bu ifadeleri vahdet-i vücûdu çağrıștırması bakımından son derece önemlidir. Fakat Ekrem Demirli'nin de belirttiği üzere vahdet-i vücûd; "Vücûd, varlık olması bakımından Hak'tır." ve "ilm-i İlâhiye'de varlığın bilgisinin hakikati bulunmaktadır." önermeleri üzerine kurulmaktadır. Varlığın/Âlemin Bir'den südûrü ile çokluğun/varlığın Bir'e ircası bakımından değerlendirilmelidir. Dolay1sıyla herhangi bir metinde yahut düşüncede bu önermelerden sadece birinin bulunması vahdet-i vücud nazariyesine ulaşılması için yeter sebep değildir. ${ }^{50} \mathrm{Hal}$ böyle olunca eserde a'yân-1 sâbitenin izlerinin bulunmaması ilgili risaleyi vahdet-i vücûd telakkisinden uzaklaştırmaktadır.

48 Sülemî, "Edebü mücâleseti'l-meşâyih ve ḥı̣̣i ḥurumâtihim”, 112.

49 Sülemî, "Edebü mücâleseti'l-meşâyih ve ḥıf̣i ḥurumâtihim”, 119.

50 Ekrem Demirli, “Gazzâlî, Mișkâtü’l-envâr, 3. Ders”, YouTube (6 Mart 2018), 01:28:10-01:30:33. 


\section{Sonuç}

Sülemînnin tasavvuf yazını tarihi açısından son derece mümtaz bir konuma sahip olmasının yanında, bir şeyh olarak ${ }^{51}$ tasavvuf alanının pratiğinde de söz sahibi olduğu görülmektedir. Özellikle dedesinin vefatının ardından Nişabur'a dönmesi ve buradaki evini düveyreye ${ }^{52}$ çevirerek ömrünün geri kalan kısmını irşâd, tedris ve telifle tamamlamış olmasının bu durumdaki payı büyüktür. Nitekim çalışmalarının meyvesi olarak sayısı yüzü aşkın eser kaleme almış; İsfahânî, Kuşeyrî, Hücvirî gibi tasavvuf alanında otorite sayılan pek çok ismi doğrudan yahut dolaylı olarak etkilemiştir.

Çalışmamızda, Sülemî̀nin Edebü mücâleseti'l-meşâyih̆ ve ḥıẓi hurumâtihim risâlesinin tercümesini yapıp adı geçen risâlenin değerlendirmesinde bulunduk. Risâlenin hacminin küçük olmasına mukâbil tasavvuf ilmi açısından sohbet kavramının maksat ve mahiyetini ortaya koyması yönüyle eşine az rastlanan bir eser olduğunu gördük. Özellikle sûfînin sohbetin hakikatine erince şeyhin ve kendisinin bir perde olduğunu ve geriye sadece Allah'ın kaldığını idrak etmesi, vahdet-i vücûd teorisinin temellerine 1şık tutmaktadır. Sülemî bu durumu Allah'ta ölmek, Allah'ta dirilmek şeklinde formüle etmiştir. Sûfî, Allah'la dirildiğinde O'nun sıfatları ile muttasıf olarak sohbetin maksadına erişir. Böylece Marûf'u müşâhede eder.

51 Sülemî'nin birçok risâlesinde şeyhliğinin izlerinin görülmesinine ilâve olarak Mekke'deki mürîdlerinin kendisine sorduğu soruları cevaplayıp onların sülûküna katkı sağladı̆̆ı soru-cevap şeklindeki risâlesi bunu açık bir şekilde göstermektedir. Ebû Abdurrahman Muhammed b. Hüseyin es-Sülemî, "Mesâil veredet min Mekke", Mecmû‘'a-i Âsâr-ı Ebû 'Abdirrahmân es-Sülemî, thk. Gerhard Böwering (Tahran: Merkez-i Neşr-i Danişgahi, 1369 hş), 3/455-461.

52 Hankâh gibi küçük tekkeler için kullanılan terimdir. Süleyman Uludağ, "Hankah", Türkiye Diyanet Vakfi İslâm Ansiklopedisi (İstanbul: Türkiye Diyanet Vakfı, 1997), 16/42. 


\section{Kaynakça}

Aclûnî, Ebü'l-Fidâ İsmail b. Muhammed. Keşfü'l-hhafầ' ve müzîlül-ilbâs 'amme'ştehere mine'l-ehâdîs 'alâ elsineti'n-nâs. thk. Yusuf b. Mahmud Hacı Ahmed. Dimaşk: Mektebetü'l-İlmi'l-Hadîs, 1424.

Ahmed b. Hanbel, Ebû Abdullah Ahmed b. Muhammed eş-Şeybânî. Müsnedü'l-İmâm Ahmed b. Hanbel. thk. Şuayb el-Arnaut - Adil Mürşid. Beyrut: Müessesetü'r-Risâle, 1998.

Buhârî, Ebû Abdullah Muhammed b. İsmail b. İbrahim el-Cu'fî. Șahịhu'l-Buhââi. Beyrut: Daru İbn Kesîr, 2002.

Cebecioğlu, Ethem. Tasavvuf Terimleri ve Deyimleri Sözlüğü. İstanbul: Ağaç Kitabevi Yayınları, 2009.

Eraslan, Soner. Tabakât Literatürünün Ortaya Çıkışı: Sülemî’nin Tabakâtu's-Sûfiyye'si. İstanbul: İstanbul Üniversitesi, Sosyal Bilimler Enstitüsü, Yüksek Lisans Tezi, 2020.

Demirli, Ekrem. “Gazzâlî, Mişkâtü'l-envâr, 3. Ders”. YouTube. Yayın Tarihi 08 Mart 2018.

www.youtube.com/watch?v=cB19lYsgq7A\&ab_channel=KlasikD\%C3\%BC\%C5\%9F $\%$ C3\%BCnceOkulu

Hücvirî, Ebü'l-Hasan Ali b. Osman. Keşfü'l-mahcûb. Kahire: Şuunü'l-İslâmiyye, 1975.

İsfahânî, Ebû Nuaym Ahmed b. Abdullah b. İshak. Hilyetü'l-evliyầ’ ve țabakātü'l-așfiyầ'. Kahire: Mektebetü'l-Hancî, ts.

Kemâhî, Osman b. Ya'kūb. el-Müheyye’ fì keşfi esrâri'l-Muvațta’. thk. Ahmed Ali. Kahire: Dâru'l-Hadis, 2005.

Knysh, Alexander. Tasavvuf Tarihi. çev. İhsan Durdu. İstanbul: Ufuk Yayınları, 2011.

Kuşeyrî, Abdülkerim. er-Risaletü'l-Ḳuşeyriyye. thk. Zerîk Marûf Mustafa. Beyrut: Mektebetü'l-Asriyye, 2001.

Ma'lûf, Luvis b Nikola el-Ma'lûf el-Yesûî. el-Müncid fi'l-lüga ve'l-a'lâm. Beyrut: Dârü'lMeşrik, 2003.

Muhammed, Yusuf Hattâr. el-Mevsû'atü'l-Yûsufiyye bi beyâni edilleti'ș-șûfiyye. Dımaşk: Dârü't-Takvâ, 2003.

Müslim, Ebü'l-Hüseyin Müslim b. el-Haccâc el-Kuşeyrî en-Neysâbûrî. Șahịhu Müslim. thk. Muhammed Sâlih Hâşim. Beyrut: Dârü'l-Kütübi'l-İlmiyye, 1994.

Serrâc, Ebû Nasr Abdullah b. Ali et-Tûsî. el-Lümac. thk. Abdülkerim Mahmud - Taha Abdülbâkī Surûr. Bağdad: Mektebetü'l-Müsennâ, 1970. 
Süyûtî, Ebü'l-Fazl Celaleddin Abdurrahman b. Ebû Bekr. el-Hâvi li'l-fetâvî. Beyrut: Dârü'l-Kitâbi'l-Arabî, 2000.

Sülemî, Ebû Abdurrahman Muhammed b. Hüseyin. Âdâbü'ṣ-ṣuhbe. Tanta: Dârü'sSahâbe li't-Türâs, 1990.

Sülemî, Ebû Abdurrahman Muhammed b. Hüseyin. “Âdâbü’ș-ṣuhbe ve hüsnü'l'uşre". Mecmû'a-i Âsâr-ı Ebû 'Abdirrahmân es-Sülemî. thk. Meir J. Kister. Tahran: Merkez-i Neşr-i Danişgahi, 1369 hş.

Sülemî, Ebû Abdurrahman Muhammed b. Hüseyin. "Beyânu ahvâli’ș-ṣûfiyye”. Tasavvufun Ana İlkeleri Sülemi'nin Risaleleri. çev. Süleyman Ateş. Ankara: Ankara Üniversitesi, 1981.

Sülemî, Ebû Abdurrahman Muhammed b. Hüseyin. "Cevâmi'u âdâbi’ṣ-ṣûfiyye”. Mecmû'a-i Âsâr-ı Ebû 'Abdirrahmmân es-Sülemî. thk. Etan Kohlberg. Tahran: Merkezi Neşr-i Danişgahi, 1369 hş.

Sülemî, Ebû Abdurrahman Muhammed b. Hüseyin. "Edebü mücâleseti'l-meşâyih ve hıfẓi hurumâtihim”. Mecmû'a-i Âsâr-ı Ebû 'Abdirrahmân es-Sülemî. thk. Kennedy Lee Honerkamp. Tahran: Merkez-i Neşr-i Danişgahi, 1369 hş.

Sülemî, Ebû Abdurrahman Muhammed b. Hüseyin. "Menâhicü'l-cârifîn". Mecmû' $a-i$ Âsâr-ı Ebû 'Abdirrahmân es-Sülemî. thk. Etan Kister. Tahran: Merkez-i Neşr-i Danişgahi, 1369 hş.

Sülemî, Ebû Abdurrahman Muhammed b. Hüseyin. "Mesâ’il veredet min Mekke". Mecmû' $a$-i Âsâr-l Ebû 'Abdirrahmân es-Sülemî. thk. Gerhard Böwerıng. Tahran: Merkez-i Neşr-i Danişgahi, 1369 hş.

Sülemî, Ebû Abdurrahman Muhammed b. Hüseyin. "Risâle fi ġalațâtu'ṣ-ṣûfiyye”. Mecmû' $a-i$ Âsâr-ı Ebû 'Abdirrahmân es-Sülemî. thk. Gerhard Böwerıng. Tahran: Merkez-i Neşr-i Danişgahi, 1369 hş.

Sülemî, Ebû Abdurrahman Muhammed b. Hüseyin. "Risâletü ravẓati'l-mürîdîn". Mecmû'a-i Âsâr-ı Ebû 'Abdirrahmân es-Sülemî. thk. Muhammed Sûrî. Tahran: Merkez-i Neşr-i Danişgahi, 1369 hş.

Sülemî, Ebû Abdurrahman Muhammed b. Hüseyin. Tabakātü'ṣ-șuffiyye. thk. Nureddin eş-Şerîbe. Kahire: Mektebetü'l-Hancî, 1969.

Tayâlisî, Ebû Dâvûd Süleyman b. Dâvûd b. Cârûd. Müsnedu Ebî Dâvûd eț-Tayâlisî. thk. Muhammed b. Abdülhasan et-Türkî. Cize: Dârü'l-Hicr, 1999.

Tirmizî, Ebû İsa Muhammed b. İsa b. Sevre. el-Câmi'u's-ṣahịh = Sünenü't-Tirmizî. thk. Ahmed Muhammed Şakir. Kahire: Mustafa el-Bâbî el-Halebî, 1978/1398.

Uludağ, Süleyman. "Hankah". Türkiye Diyanet Vakfi İslâm Ansiklopedisi. 16/42-43. İstanbul: TDV Yayınları, 1997. 